\title{
Tegniek as bemiddeling tussen lewensritme en kosmiese ritme?
}

\author{
E Wolff*
}

\begin{abstract}
Opsomming: Die doel van hierdie artikel is om na te dink oor 'n merkwaardige gebeurtenis waarin spitswetenskap en kuns mekaar ontmoet het: die astroseismologie van Conny Aerts en die komposisie van Willem Boogman. Op die punt van ontmoeting, tussen hierdie andersins uiteenlopende praktyke, is (1) 'n nadenke oor ritme en ritmering, (2) wat tegnies bemiddel is en oor (3) die verhouding tussen die alledaagse lewenswêreld en die enormiteit van die kosmos wat daardeur getematiseer word. Nadat die agtergrond van hierdie ontmoeting uiteengesit is, word 'n fenomenologiese analise van die komplekse weefsel van lewensritme uitgewerk om an te toon hoe laasgenoemde deur vertroudheid gevorm word en wat die tegniese aard daarvan is. Daar word betoog dat 'n gelukkende lewenskarakter hiervan afhanklik is. Lewensritme neem egter vorm aan onder druk van sosiale interaksie en van kulturele intervensies. In 'n wêreld wat onder die invloed van Westerse wetenskap staan, word mense se lewensoriëntering meesal gekenmerk deur 'n verlies aan kosmiese lewensoriëntasie. Die vooruitsig dat hierdie verlore band tussen die mens en die kosmos deur wetenskap of kuns (of albei) herwin kan word, word aan kritiese nadenke onderwerp.
\end{abstract}

Sleutelwoorde: Tegniek, wetenskap, astronomie, kuns, musiek, kultuur, ritme, alledaagse lewe, Conny Aerts, Willem Boogman.

Dissiplines: Filosofie, Tegnologie, Astronomie, Musiek, Chronologie.

\section{Agtergrond}

Toe Conny Aerts, aangewese besondere hoogleraar in astroseismologie aan die Radboud Universiteit Nijmegen, in April 2005 haar intreerede lewer, het sy dit goed gedink om die inhoud van haar werk vir 'n breër publiek bevatlik te maak. Haar strategie was om 'n eenvoudige analogie te gebruik: 'n analogie tussen die trilling van sterre, wat sy as astroseismoloog bestudeer, en die trilling van items waarmee meeste van ons nie net vertroud is nie, maar waaraan meeste mense ook heel geheg is, naamlik die trillings waardeur musiekinstrumente hul musiek voortbring; vandaar dus die titel van haar voordrag: Kosmische symfonieën. Deur gebruikmaking van die eenvoudige musiekmetafoor was dit dus vir haar moontlik om nie net die besonder komplekse werk van die astroseismoloog aan oningewydes bekend te stel nie, maar om ook iets van die opwinding van die ontdekkings in hierdie veld aan die gehoor oor te dra.

* Departement Filosofie, Universiteit van Pretoria. 
Daar is egter nóg 'n impak wat Aerts se voordrag op 'n mens sou kon hê en dit is presies wat die geval was met die komponis Willem Boogman. As dit so is dat sterre musiek-voortbringende eienskappe vertoon, sou 'n mens nie met menslike musiek op hierdie sterremusiek kon antwoord nie? Boogman se komposisie Sternenrest (waarvan die première op 8 November 2008 plaasgevind het) is 'n kombinasie-installasie van musiek en video (laasgenoemde deur Mateusz Herczka), waarin Boogman die sonologiese gegewens van Aerts se navorsing oor die trillings van ster HD $129929^{1}$ op musikale wyse ontgin.

Hierdie estetiese respons op die wetenskaplike ontwikkeling het op sý beurt by die Nijmeegse filosoof Chris Bremmers die vraag laat ontstaan of ons moontlik hier op die drumpel staan van nuwe pogings om die alledaagse leefwêreld in die onmenslike groot heelal tuis te bring. ${ }^{2}$ Is dit moontlik dat die nuwe wetenskap, wat in die moderne era die mens van die heelal vervreem het, nou die weg wys na nuwe maniere waarop die mens weer ' $n$ tuiste in die heelal kan terugvind? Saam met die vraag oor die maniere waarop die verhouding tussen die mens se alledaagse lewe en die ontsaglike afloop van die kosmiese prosesse verstaan moet word, konfronteer Aerts en Boogman ons ook op ' $n$ heel nuwe manier met die kwessie van sowel die verhouding tussen kuns en wetenskap as die verhouding tussen lewe en tegniek.

Die doel van my artikel is nie om hierdie sake voluit te deurdink nie, maar om binne die ruimte van een artikel 'n filosofiese perspektief hierop te gee.

\section{Oriëntasie: alledaagse lewe, lewensritme en tegniek}

Elke mens leef in 'n wêreld waarin hy of sy met 'n wye reeks dinge vertroud is. In die wêreld van ontbyt is ek vertroud met my koffie, met die ontbyttafel, met die ontbytpap, met die oggendkoerant, met my gesinsmense wat saam om die tafel sit, en dies meer. Dieselfde geld vir die werkswêreld met sy eie reeks tipiese voorwerpe, vir die sportwêreld met sy toerusting, en vir al die ander wêrelde wat ek gereeld besoek. Hierdie vertroudheid is die gevolg van 'n proses van vertroudmaking: op grond van bestaande vertroudhede reik 'n mens op 'n sekere tyd na relatief onbekende voorwerpe uit; en deur hulle gereeld te besoek, te manipuleer, te gebruik, raak mens met hulle vertroud. Om met dinge vertroud te wees, berus dus op vertroude handelinge. Om "in vertroudheid" met dinge op te tree, gee die adverbiale karakter van alledaagse optrede weer. Alle mense, ook die mees kreatiewe en die mees boheemse, tree op vanuit ' $n$ kader van vertroude handelinge. 'n Ontheemde of vlugteling ly onder die trauma van die afbreek van die moontlikheid om spontaan met hierdie vertroude handelinge voort te gaan vanweë die onteiening van die vertroude dinge en vertroude wêrelde.

Deur die loop van 'n gewone dag onderneem mense sulke herhalende aksies, waardeur hulle in die gebruik van dinge ingeoefen word. Die Franse werkwoord fréquenter (dikwels besoek) sou hierdie gereelde ontmoeting met die dinge van die bekend-wordende wêreld goed beskryf. Dit is as gevolg van die feit dat mense in hul verskillende wêrelde sekere objekte dikwels besoek dat die ontbytwêreld, die sportwêreld,

1. Sien C. Aerts, et al. "Asteroseismology of HD 129929: Core overshooting and nonrigid rotations", in Science, vol. 300 (2003), pp. 1926-1928.

2. Die uiteensetting van Bremmers se oorspronklike "Sternenrest"-program, asook meer uitgebreide gegewens oor astroseismologie en oor Boogman se komposisie, kan nageslaan word op http://www.sternenrest.nl. 
die beroepswêreld vir hulle betekenis het. Vertroudheid heet in baie kontekste ervarenheid. Iemand wat in vertroudheid of met ervarenheid in 'n bepaalde wêreld optree, is nie iemand wat geen foute begaan nie, wat nooit misgissings beleef nie, wat nooit vergeet nie; maar dit is iemand wat geneig sal wees om op die tipiese situasies wat in hierdie wêrelde opduik, met kundigheid te reageer. In die sosiale teorie van Bourdieu word hierdie langdurige predisposisie om vanuit 'n sekere vertroudheid binne 'n bepaalde situasie op te tree, 'n "habitus" genoem. Mens kan ook die habitus, op die spoor van Mauss, 'n sisteem van "lyftegnieke" noem. ${ }^{3}$

Dié aspek van die mens se alledaagse lewe wat gekenmerk word deur die vertroudheid met verskillende wêrelde en deur die vermoë daarvan om met kundigheid daarin op te tree, kan "lewensritme" genoem word. Die lyftegnieke verleen aan die alledaagse lewe 'n bepaalde ritme deur die gereelde interaksie met die bekende voorwerpe in die wêreld. "Ritme" is 'n verwarrende term: dit kan verwys na metrum, dit wil sê na die geneigdheid van 'n patroon van gebeure om identiese tydseenhede te herhaal; maar dit kan ook verwys na struktuur, soos die struktuur van 'n gedig. ${ }^{4}$ Ritme beskryf die adverbiale karakter, die vorm, ${ }^{5}$ van 'n aktiwiteit. Deur die gereelde besoek, die alledaagse frekwensie van interaksie, met die dinge van ons verskillende wêrelde word die mens ingeoefen in die vertroudheid met daardie dinge en hul wêrelde, en in oefening daarmee gehou. Met ander woorde: die alledaagse frekwensie van interaksie met dinge "ritmeer" die lewe, soos onderrig, volgens Demokritos, die lewe ritmeer (sien nota 5). "Ritme" verwys dus na die manier waarop die tydsaspek van die mens se vertroudheid met wêrelde gestruktureer is. Met "ritme" bedoel ons meesal iets tussen blote metriese herhaling en 'n algehele afwesigheid van tydlike gestruktureerdheid. Die kundigheid van alledaagse, korrekte optrede het 'n tydlike aspek wat ons as geslaagde ritme kan beskryf, terwyl 'n ritmelose bestaan een van ontheemdheid, van wêreldvreemdheid, is. ${ }^{6}$

3. Sien hieroor verder my artikel "Technicity of the body as part of the socio-technical system: the contributions of Mauss and Bourdieu" (sal in 2010 in Theoria verskyn).

4. Sien Henri Meschonnic, "Rhytme [ling.]", in Les notions philosophiques II (Encyclopédie Philosophique Universelle), Sylvain Auroux (dir.), Paris: PUF, 2002, pp. 2288-2289.

5. Volgens Benveniste ("La notion de "rythme" dans son expression linguistique", in Problèmes de linguistique générale I, Paris: Gallimard, 1966, pp. 327-335) beteken rbythmos in die oudste Griekse tekste "forme distinctive; figure proportionnée; disposition" (332) en "l’arrangement caractéristique des parties dans un tout" (330) en dít veral toepasbaar op figure, op die samestelling van materie as sodanig en op die karakter van mense (die woord van Democritos is besonder verhelderend: he didaché metarusmoi ton anthroopon - onderrig ritmeer of transformeer die mens (329) en so ook die gebruik by Euripides: rbuthmos kakoon - die tipiese kenmerk van treur, en van passie, beskryf hy as arruthmos - dit is "disproportionnée", dit wil sê buite verhouding (331)). Meer presies, en in onderskeid van ander Griekse woorde wat vorm aandui, is rhythmos gebruik om te verwys na "la forme dans l'instant qu'elle est assumée par ce qui est mouvant, mobile, fluide", en onder andere na "la disposition particulière du caractère ou de l'humeur" (333). Dit is hierdie betekenis, veral, wat dit vir my moontlik maak om die idee van rhythmos in verband te bring met dié van hexis; rbythmos sou dan "la forme improvisée, momentanée, modifiable" (333) wees van die duursame, ingeoefende instelling wat bexis (later met habitus in Latyn vertaal) genoem word.

Eers by Plato word rhythmos vir die dansende lyf gebruik, waar dit boonop aan maat en orde onderwerp word, sodat hy kan sê dat die geordende opeenvolging van stadige en vinnige bewegings (rhythmos) en die geordende opeenvolging van hoë en lae tone (harmonia) saam koorsang vorm (334). Hieruit volg die idee van ritme wat soortgelyk is aan ons hedendaagse gebruik daarvan: "c'est l'ordre dans le mouvement, le procès entier de l'arrangement harmonieux des attitudes corporelles combiné avec un mètre" (334-335). Dit is die tweede aspek van die konsep "ritme" wat in my gebruik daarvan weerspieël word.

6. Ons kan hier dink aan die ritme van gee en teruggee: die groet, die antwoord, die geskenk, die verskoning wat te vinnig of na 'n te lang aarseling gegee word, het nie die gewenste effek nie en dreig om die betrokke sosiale interaksie te laat misluk. Ek ontleen hierdie insig aan Pierre Bourdieu, "L'action du temps", hoofstuk 6 van Le sens pratique, Paris: Editions de Minuit, 1980. 
Wanneer mens die adjektief "ritmies" na analoog van die adjektief "musikaal" beskryf, word dit duidelik dat die ritme van 'n mens se lewensritme na'n bepaalde vermoë verwys. "Musikaal" noem ons iemand wat die vermoë het, of daartoe in staat is, om op grond van 'n sekere mate van vertroudheid met ' $n$ bepaalde musiektradisie, met 'n spesifieke instrument, in 'n situasie waar dit vereis word, geneig sal wees om - in vergelyking met die onmusikale persoon - 'n bepaalde tonaal-estetiese ideaal met 'n relatief hoë mate van geslaagdheid te verwesenlik; hierdie ideaal sal beskryf kan word met verwysing na die presiesheid van toon; 'n "gehoor gee" aan die gees van die geheel van die betrokke musiek-gebeurtenis; akkuraatheid of vindingrykheid van harmonisering; ensovoorts. ${ }^{7}$

Van die ritmisiteit van die lewensritme kan iets soortgelyks gesê word: "ritmies" is wat ons 'n lewe noem wat, op grond van 'n sekere mate van vertroudheid met bepaalde lewensfere of wêrelde, binne daardie wêrelde geneig sal wees om 'n bepaalde ideaal met 'n aanvaarbare mate van geslaagdheid te bereik. Met betrekking tot ritmisiteit is die ideaal om die middeweg te vind tussen die ekstreem van ritme as die voortdurende herhaling van identiese gebeurtenis-eenhede en die ekstreem van voortdurende afwisseling van ervarings sonder enige verband van bekendheid tussen hulle. Die eerste ekstreem vang die wese van die tydlike struktuur van verveling vas; die tweede ekstreem sou neerkom op totale disoriëntasie en verwarring. Vir ' $n$ mens se lewensverhaal om sin te maak, is daar ' $n$ kombinasie van ritme en onverwagsheid nodig. Uit hierdie beskrywing behoort dit duidelik te blyk dat die woord "ritme", soos in "lewensritme", nie net 'n beskrywende term is wat na die stand van strukturering van vertroude optrede in 'n bepaalde wêreld verwys nie, maar dat dit ook 'n ideaal is. Dit wil sê: die "ritmisiteit" van die lewe verwys na die moontlikheid dat 'n mens se lewe ook anders geritmeer kan word; beter geritmeer kan word. Die vraag na die beste manipulasie van die mens se lewensritme is 'n eeue oue vraag, waarna ons later weer terug sal kom.

Maar wanneer daar van lewensritme gepraat word, moet hierdie term eintlik in die meervoud gebruik word aangesien die mens se alledaagse lewe op vele wyses geritmeer word. Die wêreld van ontbyt word byvoorbeeld geritmeer deur die tyd wat my broodrooster neem om die brood te rooster, die tyd wat die ketel neem om die koffiewater te kook, die tempo waarteen ek gemaklik voel om my muesli te kou, die spoed en intensiteit waarmee ek die koerant lees, ensovoorts. Verder word my ontbyt natuurlik geritmeer deur die volgorde waarin ek al hierdie aktiwiteite orden. Afgesien hiervan staan hierdie hele kompleks van ontbytritmes onder die invloed van my keuse van die tyd waarop ek my wekker in die oggend laat lui en die verpligting om die bus betyds te haal om werk toe te gaan. Uit hierdie eenvoudige voorbeeld van die wêreld van ontbyt kan 'n hele paar eienskappe van die lewensritme afgelei word. Die lewensritme is afhanklik van die wêrelde waarin die lewe geleef word. Elke wêreld is 'n tegniese milieu wat my lewe ritmeer volgens die gebruik wat ek, as vertroude gebruiker, van die artefakte daarin maak. My alledaagse lewe word só deur ' $\mathrm{n}$ veelheid van ritmes gestruktureer. Hierdie veelheid van ritmes word gevorm aan die hand van verskillende onderdele van my tipiese optrede in die betrokke wêreld, maar staan verder ook in interaksie met ander wêrelde (die tegniese sisteem van die openbare vervoer vereis 'n reëlmatige gebruik daarvan, wat ' $n$ invloed uitoefen op die ritmes waarteen ek geneig sal wees om die verskillende elemente van my ontbyt af te handel). Uiteindelik skakel al die verskillende wêrelde van my lewe op intrigerende maniere ineen om my lewensritme in 'n bepaalde fase van my lewe te vorm. Nie al hierdie ritmiese elemente is van ewe veel belang in my lewe nie; nie almal van hulle werk op dieselfde skaal nie.

7. Dat musikaliteit afhanklik is van sulke tegniese elemente, moet ons nou reeds herinner aan die ou Griekse benaming van musiek as musiké techné - ons kom egter weer hierna terug. 
Maar van die kleinste en onbeduidendste tot die grootste en omvangrykste ritmes word my lewensritme saamgeweef. Die só saamgeweefde lewensritme is 'n wesenlike faktor wat die aard of karakter van my lewe in die algemeen bepaal. In aansluiting by die vraag oor die beste manipulasie van die mens se lewensritme (waarmee die vorige paragraaf afgesluit is), moet ons hier byvoeg: nie net het elke mens 'n komplekse alledaagse ritme nie, maar is die mens ook in staat om homself/haarself af te vra oor die gewenstheid, geskiktheid of geslaagdheid van die karakter van sy of haar eie lewe. Die sorg wat 'n mens dra vir die karakter van sy of haar lewe en vir dit wat as kosbaar of belangrik beskou word, word onderwerp aan ritmering (dink byvoorbeeld aan die manier waarop vroeëre slegte ervarings gereeld in die verbeelding besoek, of herleef, word in verwyt, of die manier waarop optrede geritmeer word in die begeerte om in die toekoms aan iemand of aan 'n taak getrou te bly).

\section{Lewensritme vorm onder druk van sosiale interaksie en kulturele intervensies}

Tot dusver het ek in die beskrywing van lewensritme op twee elemente klem gelê: die indiwidue wat deur aksie met 'n wêreld vertroud raak en die tegniese bemiddeling wat 'n rol in daardie proses speel. Die lewensritme neem egter nie alleen maar vorm aan op grond van deur die enkeling se deurleefde ervaring met dinge wat gereeld besoek word nie, maar ook op grond van die indiwidu se interaksie met ander mense en die dinge wat hulle doen. Die sosiale milieu funksioneer as aanbieder van sekere dinge wat gereeld besoek moet/kan word en ander wat vermy moet word, van maniere van doen, van inligting wat die hantering van dinge beïnvloed, en dies meer. Sosiale interaksie is by uitnemendheid geritmeerde optrede. Ek het, byvoorbeeld, vir elkeen van my vriende 'n bepaalde ritme waarvolgens ek hulle besoek. Dit beteken nie dat ek ' $n$ wiskundige formule het waarvolgens ek die getal ure tussen besoeke bepaal en wetmatig gehoorsaam nie; dit beteken dat ek vrees vir skade aan die vriendskap as 'n besoek te lank uitbly, of dat ek dalk onwelkom kan wees as ek te gou weer besoek aflê. Dink byvoorbeeld ook aan die ritme wat optredes van gee en teruggee struktureer, en waarna daar reeds hierbo verwys is (sien nota 6). Omdat ritme sosiaal aangeleer word en sosiaal gevormde gedrag is, is dit ook kultuurspesifiek. Dit word egter in alle kulture as van groot belang geag - en boonop al sedert die vroegste tye van menslike geskiedenis - dat mense sorg moet dra om hulself en andere só te begelei dat hul die mees gepaste lewensritme, dit wil sê'n gelukkende lewenskarakter, opneem.

Een van die belangrikste strategieë vir intervensie in die vorming van mense se lewensritme is die poging om die klein lewensritme van die indiwidu en die effens groter ritme van die groep op een of ander wyse te bemiddel met die afloopwyse of ritme van die kosmos. As die godsdienstige vermoede korrek is dat die kosmos as geheel intern georden is, dan kan dit die mens moontlik baat om sy of haar lewensritme in harmonie met hierdie grootse en stabiele orde te bring - so is daar byvoorbeeld in die Pythagorisme geglo dat die musikologie en wiskunde as hulpmiddels dien waarmee die verhouding tussen mense en die kosmos bemiddel kan word. ${ }^{8}$ In die Joodse en Christelike godsdienste kan mens dink aan die bemoeienis om die gelowige deur die loop van die liturgiese jaar by wyse van gepaste rites (telkens met meegaande

8. "Pythagoras had taught that life should be in harmony with the divine cosmos. [...] In Pythagoreanism harmony (barmonia) became a central tenet and was explained through numerical relations, possibly in connection with musical theory. For example, the Pythagoreans thought that the motions of the orbiting planets produced a sound which, given the belief that the intervals between the heavenly bodies corresponded to musical ratios, was harmonious." aldus Herman Schibli, "Pythagoreanism", in Routledge Encyclopedia of Philosophy, Edward Craig (ed.) CD-ROM Version 1.0, London: Routledge. 
musiek en godsdienstige toebehoorsels) in pas te bring met die algemene heilsgeskiedenis. Die datums van hierdie godsdienstige feeste word gekoppel aan die kosmiese reëlmaat, byvoorbeeld die sewende dag van die week of die herhaling van die liturgiese jaar, wat die wenteling van die aarde om die son volg. Die Sabbat- of Sondagviering is 'n uitnemende voorbeeld hiervan omdat die mens, as beelddraer van die Skepper, die Skepper se rus naboots en ook aan die skepping dieselfde rus toelaat.

\section{Die verlies aan kosmiese lewensoriëntasie weens die onttowering van die werklikheid}

Maar vir die meeste mense wat vandag in die Weste of onder sterk invloed van die Weste leef, doen hierdie tipe verhouding tot die kosmos besonder vreemd aan. In die alledaagse leefwêreld van moderne mense is dit immers heel anders gesteld met die verhouding tot die hemelruim en die kosmiese liggame. Watter plek neem die heelal en die hemelliggame in mense se lewens in? In die alledaagse leefwêreld speel die verhouding tot die hemelliggame feitlik geen rol nie. Die lig van die son verskyn smorens, word intenser en verdwyn dan weer, maar meesal leef mense in daglig teen ' $n$ bepaalde temperatuur en nie in verhouding met die son nie. Dieselfde geld vir die seisoene: ons verander ons kleredrag na gelang van die tyd van die jaar, pas ons by die meteorologiese verskynsels aan, maar het gewoonlik geen verhouding tot die feit dat die aarde om die son draai nie. Ek tematiseer die feit dat ek op die aardbol woon feitlik nooit nie, maar ek rig my liggaam en handelinge daagliks ten opsigte van die gravitasieveld wat ek onbewustelik steeds in berekening hou. Die tyd waarin ek daagliks leef, is 'n abstrakte meting van vier-en-twintig eenhede (wat nooit voldoende is nie!) en het nie veel te make met die feit dat die aarde om sy eie as draai nie. Net so begeef ek my in 'n atmosfeer van dae wat verbysnel, wat op 'n kalender afgemerk kan word; maar weereens het hierdie stroom van tyd waarin ek my bevind met die beweging van kosmiese liggame nie veel te make nie.

Kortom, die mees opvallende verhoudings wat die moderne mens met die hemelliggame en hul omwentelings het, is van die orde van ' $\mathrm{n}$ deurleefde vertroudheid met die effekte van die plaaslike hemelliggame, eerder as verhoudings tot die hemelliggame self - lig, warmte, gravitasie, tyd omring my soos die atmosfeer. Uitsonderings is raar: die sonbaaier waardeer die strale van die son, die swemmer hou die maangetye dop om die seegetye daarvan af te lei. En hier praat ek telkens nog net van die son, maan en aarde. Van tyd tot tyd flits 'n maansverduistering of 'n komeet as rare astronomiese verskynsel op, maar oor die algemeen het die moderne mens met die verdere hemelliggame nie veel te make nie. Selfs in kringe van godsdiensbeoefening is die verhouding tot die hemelliggame dermate gesekulariseer dat gelowiges nie veel meer oor die hemelliggame te sê het nie as miskien 'n opmerking oor die skoonheid waarmee die Skepper die hemel sou gemaak het. Weens besoedeling en stadsligte kan daar in elk geval nie veel van gesien word nie. Betlehemster word waardeer as 'n fraai versiering op 'n Kerskaartjie of in 'n winkelvenster, maar niemand hou die sterre dop om aanduidings vir suksesvolle lewensbestuur daaru af te lees nie. Diegene wat hul lewenslot aan die sterre verbind sien, word eerder as 'n sosiale randverskynsel gesien wat kontak met die werklikheid verloor het, en selfs in hul geval is dit nie seker dat hul verhouding tot die sterre is en nie eerder tot die astrologiese teks nie.

Dit gebeur egter ook dat mense op verskillende wyses gekonfronteer word met die beeld wat die moderne wetenskap op die heelal bied. Dit kan gebeur dat hierdie konfrontasie van so intens is dat dit die mens tot 'n heroorweging van sy of haar posisie in die kosmos dwing. In stede van 'n oriënterende uitwerking kan so 'n konfrontasie eerder 'n effek van verslae of angstige disoriëntasie en ontwrigting van die alledaagse, vertroude omgang met die omgewing hê. 
Sprekend van hierdie reaksie is die bekende woorde van Pascal:

Wanneer ek dink oor die korte duur van my lewe, wat verdwyn in die ewigheid wat die klein ruimtetjie wat ek beslaan en selfs wat ek sien, voorafgaan en opvolg, verlore in die oneindige omvang van die ruimtes waarvan ek nie weet nie en wat nie van my weet nie - dan vul dit my met angs en verbasing dat ek my hier bevind eerder as daar, want daar is geen rede waarom dit hier moet wees eerder as daar nie, waarom dit nou moet wees eerder as op 'n ander tyd nie [...]. Die ewige stilte van hierdie oneindige ruimtes vul my met angs. ${ }^{9}$

Die vreesbevange nadenke van Pascal oor sy verhouding tot die heelal is dié van 'n mens wat die gebrekkigheid van heersende bemiddelingstegnologieë besef. Onder só 'n indruk van die versaking van bemiddeling word die kosmos as indifferent of onverskillig ervaar: die klein lewetjie van Pascal gaan die grote heelal nie aan nie, die heelal kan nie omgee wat met Pascal gebeur nie. Daarom is die "ewige stilte" van die heelal nie in die eerste plek 'n stilte wat geen geluid - laat staan nog musiek - maak nie, maar 'n stilte van dit wat oor my lewenslot en oor die karakter van my lewe niks te sê het nie, wat geen bydrae tot my oriëntasie in die geheel maak nie. Op dit wat geen ritme het nie, kan nie gedans word nie. Hierdie reaksie van Pascal behoort ons ook nie te verbaas nie: die ekstreme grootte van die heelal, die oortuiging van die leweloosheid daarvan, die verdaging van die doelmatigheid van die kosmos deur die moderne natuurwetenskaplike verklaringswyse, laat nie veel aanknopingspunte vir'n lewensoriënterende tegniek nie. In 'n teks waarin hy oor hierdie fragmente van Pascal nadink, lewer Hans Jonas die volgende kommentaar:

With the ejection of teleology from the system of natural causes, nature, itself purposeless, ceased to provide any sanction to possible human purposes. [...] [Nature, or the universe - EW] leaves values ontologically unsupported, and the self is thrown back entirely upon itself in its quest for meaning and value. Meaning is no longer found but is "conferred". Values are no longer beheld in the vision of objective reality, but are posited as feats of valuation. As functions of the will, ends are solely my own creation." 10

Die verskillende maniere waarop mense te werk gaan om waardes te skep en dit aan elemente van die wêreld en die heelal toe te ken, vorm die spektrum van verskillende verhoudings wat die moderne mens tot die heelal het. Hierdie spektrum is dus die variasies van betekenis tussen die pole van angswekkende disoriëntasie en gemaklike vergetelheid van die alledaagse lewe. ${ }^{11}$

9. “Quand je considère la petite durée de ma vie, absorbée dans l'éternité précédant et suivant le petit espace que je remplis et même que je vois, abîme dans l'infinie immensité des espaces que j’ignore et qui m'ignorent, je m’effraie et m'étonne de me voir ici plutôt que là, car il n’y a point de raison pourquoi ici plutôt que là, pourquoi à présent plutôt que lors [...] Le silence éternel de ces espaces infinis m’effraie.” Blaise Pascal, Pensées, Ch.-M. des Granges (volgens die uitgawe van Brunschvicg), Paris: Garnier Frères, 1961 (oorspronklik 1670), fragmente $205 \& 206$ (my vertaling).

10. Hans Jonas, The phenomenon of life. Toward a philosophical biology. Chicago \& London: University of Chicago Press, [1966]1982, pp. 214-215 (my beklemtoning).

11. In wat volg, gaan ek die spektrum van strategieë waardeur die mens sinskeppend met die heelal omgaan (soos in die Jonas-aanhaling), beskryf aan die hand van die tegnies-wetenskaplike en estetiese 


\section{Twee vorme van tegniese bemiddeling: wetenskap en kuns}

Vanuit die verskillende strategieë waarvolgens mense in die moderne era poog om 'n verhouding tot die hemelliggame daar te stel - dit is, maniere van bemiddeling - is twee van besondere belang wanneer daar oor die Sternenrest-projek (sien paragraaf 1 en nota 2 hierbo) nagedink word: die een is wetenskap (hier by name astroseismologie) en die ander is kuns (hier spesifiek musiek). Ek noem altwee hierdie vorme van bemiddeling "tegnieke", nie om die praktyk van wetenskap en dié van musiek tot die tegniese aspekte daarvan te reduseer nie, maar ten einde klem te lê op die onmisbaarheid van tegniek in sowel die wetenskaplike as die musikale bemiddeling. Wetenskaplike ontdekkings en die vorming van wetenskaplike teorieë is ondenkbaar sonder die mediasie van tegniese artefakte; insgelyks is dit wat eens op 'n tyd in Griekeland musiké techné genoem is, onmoontlik sonder die tegniese middele wat die musiek moontlik maak. Deur die klem te plaas op die techné of ars van wetenskap en kuns word gewaak teen die fout om te dink dat met "bemiddeling" bloot ' $n$ mentale aktiwiteit bedoel word én hou ons die vraag aangaande die ritmering van lyftegnieke (en só van die alledaagse lewe) in die oog. Die maaksels wat deur die tegnieswetenskaplike bemiddeling voortgebring word, is wetenskaplike teorie, en die maaksels van die tegniesmusikale produksie (poiésis) is 'n estetisering van 'n bepaalde tema (meer hieroor later).

bemiddelingsmoontlikhede. Ek sal my daarin laat lei deur 'n tematiese toe-eiening van die historiese insigte in Odo Marquard se opstel "Kant und die Wende zur Esthetik", Zeitschrift für philosophische Forschung 16, 1962, pp. 231-243 \& 363-374. Marquard se argument kom op die volgende neer:

Ten spyte daarvan dat daar in die Westerse filosofie 'n lang geskiedenis van anti-kunstenaarsentiment is, ontluik die estetika in die moderne era tot' $n$ besonder belangrike plek in die filosofie. Dit gebeur in 'n konteks waar filosofie die taak opneem om nie vir 'n bepaalde doel te werk nie, maar sigself die taak oplê om van die “überlieferten religiösen Bindungen” te ontsnap (235). Twee groot rasionele emansipasiestrategieë domineer die geskiedenis van moderne filosofie: dié van die wetenskaplike denke en dié van die eties-historiese denke. Die estetika kom sterk na vore - só Marquard se betoog - waar die perke van die wetenskaplike rede reeds duidelik geword het (in besonder die onvermoë om oortuigend oor laaste doele van menslike optrede te praat) en waar die eties-historiese denke nog nie behoorlik die rol as dominante intellektuele mag oorgeneem het nie (vgl. 237). Kant se estetika sou kenmerkend van hierdie oorgang wees: die ware wetenskaplike rede kan nie, en behoort nie, leiding aan die mens se lewe te gee nie (aldus sy verdaging van 'n sekere soort metafisika) (241), maar die morele rede, hoewel dit wel die uiteindelik gewenste menslike optrede formeel kan beskryf, beskik oor geen middele tot die verwerkliking van daardie doel nie (vgl. 365-366). Van die magteloosheid van die morele rede word Kant na die estetika gedryf. Of die estetika, wat deur Kant ten dienste van die etiek gestel word, in werklikheid 'n instrument tot die politieke verwerkliking van die morele rede word en of dit eintlik 'n plaasvervanger daarvan word, bly volgens Marquard by Kant onbeslis (370). Ná Kant groei die bewustheid dat kuns in werklikheid nie as instrument van die politieke verwerkliking van etiek funksioneer nie, en hierop reflekteer Marquard soos volg: “je weniger das Ästhetische und die Kunst durch die soziale Wirklichkeit des Sittlichen und der Geschichte sich definiert, getragen, gerechtfertigt fühlt, um so stärker wird ihr Bedürfnis, sich durch den Anschluß an eine andere, eine außersoziale und außergeschichtliche Wirklichkeit zu rechtfertigen. Solch eine außergeschichtliche Wirklichkeit ist die Natur, eine außersoziale die nicht 'als Naturwissenschaft gegebene' Natur. [...] zur Ästhetik gebört die latente Bereitschaft, die Naturphilosophie sich zu assoziieren, sie schließlich zur Hauptphilosophie zu machen und damit potentiell zur Lebensphilosophie überzugehen. Diese Bereitschaft schlummert, solange Ästhetik als Instrument, sie erwacht, sobald Ästhetik als Ersatz des geschichtlichen Denkens gesucht und gemeint wird.” (371). By name die estetika van die Romantiek maak sigself los van die polities-historiese ontwikkeling van die mens en laat sig bepaal deur die verhouding met die verre natuur (373). Waar hierdie natuur egter as teenwoordig in stede van ver ervaar word, by Schopenhauer en Nietzsche, tree die "Herrschaft der entzauberten Interessenwelt" na vore (374).

Die vraag wat uit hierdie historiese argument afgelei en aan Willem Boogman, komponis van Sternenrest, gestel moet word, is hoe sy werk binne die spanningsveld tussen natuur en geskiedenis gesitueer moet word. Word die verre natuur besing onder regverdiging van die feitlikheid van die natuurwetenskaplike gegewens wat as inspirasie daarvoor gedien het, of dien die wetenskaplike gegewens tot die heroriëntasie van die mens in die groter, kosmiese konteks? Ek sal hierdie vraag in die res van die hoofstuk uitwerk. 
Twee praktyke wat die moontlikheid besit om sin te skep, dit wil sê twee potensiële vorme van bemiddeling tussen mens en heelal, is dus vir ons hier van belang. Aan die een kant die bemiddeling deur wetenskaplike beskrywing en teoretisering, wat sonder die voortdurende verbetering van waarnemingsen meetinstrumente heeltemal ondenkbaar is (hier sal ek na Conny Aerts se intreerede as voorbeeld kyk); aan die ander kant die estetiese bemiddeling (waarvan Willem Boogman se Sternenrest, wat by Aerts se wetenskaplike bevindings leen, as voorbeeld beskou sal word).

\subsection{Tegnies-wetenskaplike bemiddeling: tussen ongekendheid en bekende vreemdheid}

Wanneer daar eerstens na die tegnies-wetenskaplike bemiddeling van mens en heelal gekyk word, moet ons dadelik in gedagte hou dat die alledaagse, vreedsame, vergeetagtige, gesekulariseerde nie-verhouding tot die hemelruim histories deur die tegnies-wetenskaplike bemiddeling gekonstitueer is. Dit is laasgenoemde wat 'n nuwe, heersende tendens in die algemene "onttowerde" beskouing van die mens se posisie in die heelal ingelui het (hierop kom ek nog later weer terug). Hierdie verhouding word steeds op sekere plekke getematiseer, dit wil sê onder die aandag van mense gebring. Televisie-uitsendings waarin die bevindinge van astronomie bekendgestel word, is heel gewild. Kinders leer op skool minstens die basiese elemente van ons eie sonnestelsel ken. Tydskrifte en wetenskapsentrums speel ook 'n rol in dié dele van die wêreld waar dit beskikbaar is. Skrywers soos Sagan en Hawking behaal groot sukses met hul boeke. Dit blyk dat daar, ten spyte van die feitlik algehele afwesigheid van 'n verhouding tot die sterrehemel, in die alledaagse lewe tog taamlik wyd aanvaar word dat dit goed is om 'n basiese kennis van die algemene gegewens te hê, en dat daar tog 'n sektor in die samelewing is wat verder daaroor gestimuleer wil word (sien ook internetwebtuistes en klubs vir amateursterrekundiges). In die naam van algemene kennis, persoonlike verryking, of bevrediging van die passie vir kennis ondergaan mense dus sporadies blootstelling - in die gedaante wat dit deur die populariseerders van eietydse astronomie aangebied word - aan die hemelruim, wat uiteindelik deel van ons kulturele gemeengoedere word.

Om die hoogs gespesialiseerde wetenskaplike kundigheid op 'n bevatlike manier aan 'n nie-spesialispubliek te bring, is op sigself reeds 'n groot uitdaging. Afgesien van populariseringsmedia (soos boeke en TV, waarna ek hierbo verwys het) is een van die interessante aspekte van hierdie populariseringsproses die inspan van metafore uit die mens se alledaagse leefwêreld. Veral die gebruik van musiekmetafore ten einde die digte vaktaal van die spitswetenskap met pedagogiese effektiwiteit aan te bied, is vir ons hier van belang. ${ }^{12}$

12. Naas die voordrag van Conny Aerts het ek toevallig op 'n ander gebruik van die musiekmetaforiek afgekom, naamlik soos gebruik deur Trinh Xuan Thuan, die Viëtnamees gebore Frans-Amerikaanse astrofisikus, in die onderhoud "L'univers joue du jazz", in La Vie van 7-14 Augustus 2008, pp. 18-24. Hier antwoord Thuan soos volg op die stelling "Vous évoquez souvent la musique en astrophysique": "A cause de l'harmonie qui règne dans l'univers. Il y a quelques semaines, j’ai participé à un festival de jazz, où j’ai expliqué que la nature joue du jazz. L'univers est régi par des lois imposées dès la première fraction de seconde, comme la gravité, l'électro-magnétisme, etc. Mais il ne s'agit pas d'un déterminisme comme Newton ou Laplace le pensaient au XVIIe siècle. L'univers brode sur les lois physiques comme un joueur de jazz brode sur une trame musicale en fonction de son inspiration, du public, et donc le morceau n'est jamais le même. La théorie du chaos, la mécanique quantique, ce qu'on appelle le flou quantique, permettent à la nature de broder sur des lois physiques et de créer du nouveau. Il y a toujours du libre arbitre."

'n Mens kan nie anders nie as om hier te let op die terme wat implisiet dui op die toeskrywing van 'n soort subjektiwiteit of agentskap aan die natuur (die natuur "speel" jazz, die heelal "ontwikkel" die tema van die natuurwette, die natuur "skep", daar (waar?) is altyd "vrye wil"). 
In haar intreerede, Kosmische symfonieën, ${ }^{13}$ lei Conny Aerts haar gehoor in die basiese gegewens van die astroseismologie in. Sy doen dit onder andere deur te verduidelik dat sterre "klanke" maak, omdat die trillings wat deur sterre voortgebring word, vergelykbaar is met dié wat deur musiekinstrumente voortgebring word. As daar dan eers bepaal is dat ' $\mathrm{n}$ ster soos ' $\mathrm{n}$ groot, driedimensionele snaar is, kan die wetenskaplike daaruit 'n string vrypostige en verbeeldingryke beelde ontwikkel: die ster as snaar "speel" note, soos 'n "musikant" wat "kosmische symfonieën" en "prachtige partituren" aan 'n gehoor aanbied. ${ }^{14}$ Saam met die vergelyking met musiek sluip daar' $n$ paar ander beelde in. In die eerste twee gevalle (speel, musikant) stel die musiekmetafoor haar in staat om agentskap by die hemelliggame in te lei; in die twee volgende metafore ("kosmische symfonieën", "prachtige partituren") word sowel estetiese evaluasie as die herkenning van musikale vorm ingebring; en ten slotte, wanneer daar van 'n gehoor gepraat word, word die idee van die sosiale opset van die uitvoering betrek. Aerts is natuurlik goed hiervan bewus en plaas daarom wyslik die betrokke terme in aanhalingstekens op dié plekke waar dit nie ooglopend metafories bedoel word nie, of waar misverstand kan ontstaan. Mens moet verder daarop bedag wees dat die verdere inhoud van haar voordrag ons noop om te erken dat die musiekmetaforiek nog verder relativeer moet word. Wat sy oor die "simfonie" van sterre sê, doen sy in die eerste plek op sterkte van die sukses wat behaal is met astroseismologiese studies van die son. Maar oor vele ander sterre kom gegewens kort: om die selfde graad van kundigheid oor die ander sterre se "musiek" te vorm,

is het noodzakelijk dat we honderden oscillaties detecteren in plaats van de enkele die tot nu toe gevonden werden, omdat zij niet toelaten een onderscheid te maken tussen stermodellen met en zonder overschieten, al of niet met starre rotatie. ${ }^{15}$

As ek Aerts reg verstaan, moet hierdie uitspraak in haar musiekmetaforiek omvertaal word om te sê: van hierdie sterre weet ons nie of ons luister na 'n rockkitaarkonsert, of na 'n Indiese siterkonsert, of na 'n apie wat met 'n lepel op 'n klaviersnaar slaan nie - al wat ons weet, is dat die kosmiese driedimensionele snaar op verskillende maniere tril. Hierdie is 'n belangrike punt om te maak, bloot om 'n idee te vorm van hoe ver die wetenskaplike bemiddeling op hierdie "musikale" vlak tussen mens en ster strek. Die ylheid van die bemiddeling, wat te wyte is aan die vlak van huidige tegniese bemiddeling tussen mense en die sterre, maak dit duidelik dat daar eintlik nie van "musiek" gepraat kan word nie - omdat daar geen musikant, geen partituur, geen musiekvorm, geen sosiale vorm van aanhoor, geen kriteria vir die evaluering van die geslaagdheid daarvan, geen aanhoorbare begin of einde, is nie en die geheel van die werklike klanke nie genoegsaam deur die beskikbare tegniese middele opgevang word nie. Daarom moet mens toegee dat, ten spyte van haar pedagogies geslaagde metafoor, ook Aerts ons nie veel verder bring as 'n onverskillige heelal, as die "ewige stilte van hierdie oneindige ruimtes" wat Pascal so met angs vervul het nie. Selfs as daar toegegee word dat sterre klanke maak, dan is dit nie musiek wat vir ons gespeel word nie, maar lukrake klanke (of klanke wat deur natuurwetmatighede bepaal word) wat op menslike skaal as't ware van ewigheid tot ewigheid voortgebring word, sonder dat die grootste deel van die mensdom ooit daarvan bewus was. Dat dít eintlik ook Aerts se versweë opvatting is, kan afgelei word uit die afwesigheid van 'n aantal musiekmetafore wat heel natuurlik by hare sou gepas het: op geen letterlike of figuurlike manier

13. Conny Aerts, Kosmische Symfonieën, Intreerede as besondere hoogleraar in astroseismologie aan die Radboud Universiteit Nijmegen, 2005.

14. Kosmische Symfonieën, op. cit. pp. 7-8.

15. Kosmische Symfonieën, op. cit. p. 17. 
stel sy voor dat ons die sterresimfonie met applous moet beantwoord nie, met ander woorde ons hoef nie ons dank daarvoor te betuig nie; ook word ons nie opgeroep om saam by die omringende musiek in te val of op die kosmiese musiek te dans nie. ${ }^{16}$ Die klanke van die sterre het die struktuur van musiekklanke, maar sonder dat die minimum voorwaardes vir die toe-eiening daarvan vervul word. Ons sou dit daarom hiëroglifiese klanke kon noem: dit het die struktuur van betekenis, sonder dat ons in staat is om betekenis daaruit af te lei. Aerts se bydrae tot die tegnies-wetenskaplike bemiddeling tussen mens en sterre behels die ontsluiting van die bestaan van sterretrillings wat in struktuur soortgelyk is aan dié van iets wat ons ken: die trilling van 'n snaar (van 'n musiekinstrument). Die wetenskaplik-tegnies blootgelegde tonale hiërogliewe bied uitstekende materiaal vir persoonlike verryking, vir die uitbou van algemene kennis, of die bevrediging van die passie vir kennis, maar is ondansbaar: dit leen sigself nie tot die ritmering van 'n mens se bestaan nie.

\subsection{Estetiese bemiddeling: tussen toe-eiening en vervreemding}

Maar dit is nie al nie. Hierdie gesofistikeerde tegnies-wetenskaplike ontdekking fasiliteer ' $n$ estetisering van die nuut ontdekte verskynsel - of dít minstens, vir sover 'n kunstenaar die geleentheid wil aangryp. Die komponis wat van hierdie hiëroglifiese tone 'n geleentheid tot komposisie wil maak, staan voor 'n besonder veeleisende taak. ' $n$ Denkeksperiment van Clifford Geertz ${ }^{17}$ kan as analogie dien om die aard van hierdie taak te help waardeer. Veronderstel twee seuns wat elkeen die ooglid van een oog vinnig sluit en dan weer oopmaak. By die eerste is dit 'n knipoog waarmee hy 'n teken van sameswering aan 'n maat stuur ("a wink"), by die tweede is dit 'n onwillekeurige sametrekking van ooglidspiere ("a twitch"). Nou kan mens die twee gebeurtenisse op twee verskillende maniere probeer beskryf. Vir die "dun beskrywing" is die twee gebeure identies: dit laat ons nie toe om die twee voorvalle van mekaar te onderskei nie; die "dik beskrywing" onderskei tussen die tweede seun wat een ding doen (die ooglid knip) en die eerste seun wat twee dinge doen (die ooglid knip en só 'n teken aan 'n maat stuur). Die "dun beskrywing" van altwee gevalle is dieselfde: 'n seun sluit een oog vinnig en makk dit weer oop; die "dik beskrywing" verander telkens na gelang van hoe die optrede deur die beskrywer geïnterpreteer word.

My vermoede is nou dat natuurwetenskaplike spelreëls oor die algemeen, en die spelreëls van astroseismologie in die besonder, net "dun beskrywing" vir sigself veroorloof. Dit streef eers, en veral, na die inwin van dit wat telkens deur enige wetenskaplike wat dieselfde waarnemings- en metingstegnologië gebruik, op dieselfde manier beskryf sal kan word. Nogtans - as my analogie enigsins waarde het - kan mens uit Aerts se gebruik van die musiekmetafoor aflei dat haar natuurwetenskaplike voorstelling van die sterretrillings ' $n$ ander verhouding tot die natuur ${ }^{18}$ toelaat, dat haar "dun beskrywing" 'n "dik beskrywing", maar as natuurwetenskaplike voorstelling alle oordeel oor sodanige "dik beskrywings" moet opskort. My

16. Mens merk hierdie punt goed op wanneer jy Aerts se voorstelling van die kosmiese simfonieë met 'n voor-moderne perspektief op die sterre vergelyk: in antwoord op God se skepping van die sterre, kan die sterre opgeroep word (al is dit figuurlik bedoel) om Hom saam met die digter te prys (aldus Psalms 8 en 148 onderskeidelik).

17. Clifford Geertz, "Thick description. Toward an interpretive theory of culture" in The interpretation of cultures: selected essays, New York: Basic Books, [1973]2000, pp. 3-30, veral p. 6. Ek vereenvoudig Geertz se denkeksperiment, wat hy van Gilbert Ryle oorgeneem het.

18. Sien hieroor die nota hierbo oor Marquard se lesing van die estetika se aansluiting by 'n ander natuurpersepsie. 
bedoeling met hierdie analogie is nie om sonder meer te veronderstel dat Boogman se benadering tot komposisie een van beskrywing is, so asof die enigste taak van kuns die weergee van die werklikheid is nie. Wat ek wel sê, is dat sy Sternenrest-komposisie daarop aanspraak maak dat dit die sterretrillings en die lewe van die ster estetiseer, en nie bloot'n lukrake spel van klanke as inspirasie gebruik nie. ${ }^{19}$ Omdat Boogman die kosmiese "oogknip" (die sterretrilling) as vatbaar vir 'n "dik beskrywing"-analoë komposisie neem (dit wil sê as objek vir estetisering en nie net as objek van wetenskaplike voorstelling nie), ontgin hy die ruimte wat deur Aerts vir verdere interpretasie gelaat is, en verruim hy dit verder.

Dit is hierdie estetisering van die wetenskaplike bemiddeling wat die toe-eiening van die nuwe ontdekking vergemaklik. Die musikale verwerking of ontwikkeling op die tema van wetenskaplik-tegniese gegewens van stertrillings is, minstens in 'n eerste beweging, 'n versagting van die harde vreemdheid of andersheid van die nuwe ontdekking wat ek as tonale hiëroglief getipeer het. Hierdie versagting kan gesien word aan die verskuiwing van die eienskappe van die stertrilling na die eienskappe van Boogman se komposisie: in die verkorting van die duur van die klanke, in die aanbieding van die musiek in 'n menslik bevatlike akoestiese milieu, teen 'n menslik tolereerbare volume en teen hoorbare frekwensies, in die gebruikmaking van instrumente wat bekend is uit die gehoor se musiektradisie, ensovoorts. Só beskou, dien die estetisering om die vreemdheid van die ontdekking te tem.

Die musikale estetisering van die nuwe bevindinge van die astroseismologie bevat die potensiaal om in te speel op die beeld of die stemming van die grootste horison van die mens se alledaagse lewe. Dit sal seker te veel wees om te beweer dat so 'n estetisering die alledaagse lewe op 'n wesenlike manier kan ritmeer, maar daar lê in die komposisie minstens 'n suggestie daarvoor: dit wat deur die musiek as die skoonheid of uitsonderlikheid van die kosmiese musiek voorgehou word, laat 'n mooi lewe toe of spoor die hoorder dalk aan tot 'n soeke na 'n uitsonderlike lewe. Of miskien: die geboorte, grootsheid en afloop van die lewe van 'n ster kan deur die estetisering daarvan bydra tot die stemming van my eie geboorte, leeftyd en sterfte. Anders gestel: die ruimte vir'n koördinasie van kosmiese en lewensritme word oopgehou. Vanuit hierdie perspektief kan die Sternenrest-komposisie waarskynlik nóg as instrument tot die politieke-historiese doelstellings van die mensdom, nóg as plaasvervanger van sulke doelstellings gesien word (volgens die terme wat ek aan Marquard ontleen) - dit is eerder 'n plekhouer of oopruimer van die moontlikheid van 'n akkoord tussen mens en kosmos. Sekerlik bly dit, soos Jonas beweer, 'n menslike poging tot sinstigting: reeds die toe-eienbaarheid van die vreemdheid van die sterre sou 'n eerste stap in dié rigting wees. Dit moet egter nie misgekyk word nie dat daar' $n$ poging is om die sterre eers te beluister, dit wil sê om sigself aan hulle bloot te stel voordat hulle met eie gedagtes, teoretisering en estetisering oordek word. Dit bly waar, ook al is die toegang wat ons as mense tot hierdie tipe kosmiese verskynsels kan hê, ons beluistering daarvan, noodwendig weer tegnies bemiddel, dit wil sê die gevolg van 'n gewilde poging en prestasie van verneming. Die natuurwetenskaplike ingesteldheid sorg myns insiens vir 'n waaksaamheid en 'n lewende begeerte om aan die objek self blootgestel te word: wel bewus van die ingryp wat (tegniese) waarneming maak, bly die wetenskap 'n poging om daardie ingryp so ver moontlik te verdiskonteer in 'n beweging van openheid tot dit wat die beskrewe objek ook al mag bied.

19. Sien die notas oor die realisasie: "Centraal in Sternenrest staat GLAS (naar de ster HD 129929). De muziek hiervan is gemodelleerd naar de meetgegevens en uitkomsten van het onderzoek naar de ster HD 129929 zoals geformuleerd door Conny Aerts in het wetenschappelijke tijdschrift Science (2003). Tot de meetgegevens behoren onder meer zes sterfrequenties en gegevens over verschillende rotatielagen en rotatiesnelheden in de ster." (http://www.sternenrest.nl/files/muziek.html). 
Maar juis in hierdie punt lê 'n totaal ander moontlikheid van die estetisering van wetenskaplike bevindings skuil. Terwyl die estetiserende ontginning van die tegnies-wetenskaplike voorstelling 'n verdere moontlikheid in die bemiddeling tussen mens en hemelliggame aandui, bly die musiekopvoering vir sy geslaagdheid afhanklik van die wetenskaplike voorstelling: die gehoor weet hulle luister na 'n estetisering van sterretrillings en dat daar, volgens die huidige stand van navorsing, werklik sulke goed bestaan hierdie kundigheid vorm die agtergrond waarteen die musiek aangehoor word. Maar onthou, ek het bevind dat die wetenskaplike bevinding goed as 'n tonale hiëroglief beskryf kan word - en dit is vanuit hierdie hiëroglief dat die estetisering sin maak. As sodanig kan mens ook sê dat die estetisering gelyktydig 'n teenoorgestelde rol speel as die fasilitering van 'n versagtende toe-eiening: die estetisering bring die ontstellende andersheid van sterre tot bý mense wat andersins deur die alledaagse vergetelheid daarteen beskerm sou wees. Anders gestel, insoverre die komposisie getrou bly aan die wetenskaplike gegewens waardeur dit gevoed word, is dit nie net 'n gewaagde poging om die betekenisstruktuur te vergroot (om die kosmiese "twitch" as 'n "wink" te lees) nie, maar is dit ook 'n naderbring van die onleesbaarheid, die onreduseerbare vreemdheid, daarvan.

Dit is ' $n$ vreemdheid of andersheid wat nie net geleë is in die sterre se afstand, ouderdom en grootte nie, maar veral in die feit dat hulle stom bly ten spyte van hulle klankstruktuur. Die tegnies-wetenskaplike bemiddeling stel ons, deur die estetisering van sterre, in staat om die konfrontasie met die hiëroglifiese karakter van sterre nog meer akuut te maak. As sodanig speel dit ontwrigtend in op enige mistifisering of vergetelheid van hierdie vreemdheid. Hierdie is 'n ingreep op die alledaagse lewensritme, 'n ontwrigting, wat tot nadenke en selfs tot heroriëntering van die lewe kan lei. Maar aangesien so 'n heroriëntering gedoen moet word sonder dat dit wat ontwrigtend inwerk self reeds 'n oriënteringspunt verskaf, kan die hele ervaring maklik tot angstige vertwyfeling lei. Gegewe dit wat die komponis as vertrekpunt neem, is die risiko dat die bemiddeling een sal wees wat mense uit hul gemaklike vergeet van die andersheid van die heelal ruk en voor die Pascaliaanse vervreemding werp. In 'n kulturele wêreld waar daar weens die onttowering van die werklikheid geen simboliese meganismes bestaan om 'n plek te gee aan hierdie vreemdheid nie, is disoriëntasie dus die voortdurende risiko van bemiddeling tussen mens en hemelliggame, hetsy deur die wetenskap, hetsy deur estetisering.

\section{Van wetenskap en kuns terug na die alledaagse}

Die estetisering van wetenskaplike bevindinge lei dus tot die dubbelsinnige moontlikheid van fasilitering, van toe-eiening en die oophou van die ruimte van harmonisering tussen mens en hemelliggame aan die een kant, en tot die moontlikheid van skok of disoriëntasie aan die ander kant. Maar aangesien nóg hierdie spitswetenskap, nóg die avant garde-musiek deel uitmaak van die alledaagse, is kanse goed dat sowel die toe-eieningspotensiaal as die ontwrigtingspotensiaal 'n kortstondige uitwerking sal hê. Die kennis van vreemde, verre stertrillings kan veilig in die kwarantyn van algemene kennis of persoonlike verryking tuisgebring word. Dieselfde geld vir die estetisering daarvan: as hierdie musiek nie deur sosiale tegnieke van ritualisering tot (sekulêre) liturgie gevorm word nie, met ander woorde, as die musiek nie in die kanon van belangrike werke opgeneem word en van sowel 'n program van publieke herhalings as van 'n verklaring van die uiteindelike doel of diagnose van die menslike kondisie voorsien word nie, is daar nie veel hoop dat dit as tegniese bemiddeling simbolies effektief ${ }^{20}$ sal wees nie. Sonder so 'n groter sosiale tegnologie

20. Sien my bespreking van die tegniese voorwaardes vir simboliese effektiwiteit in "Mediologie en hermeneutiek", in Tydskrif vir Geesteswetenskappe 47/1, Maart 2007, pp. 81-94, hier pp. 89-90. 
waardeur mense deur gereelde blootstelling aan die estetiese ervaring ingeoefen kan word in ' $\mathrm{n}$ goed omskrewe ervaring, sal die ritmering van die alledaagse deur hierdie musiek 'n uitsonderlike verskynsel bly. Anders gestel: vir sover hierdie musiek met die toeëienings- en ontwrigtingspotensiaal daarvan nie in 'n groter tegniese sisteem ingewerk word om daardeur effek te kan uitoefen op die karaktergewing, op die ritmering, van mense se lewens nie, is dit veel meer waarskynlik dat die aangryping deur die musiek slegs enkele individue sal raak en dat dit, as ervaring, vir die grootste gros deur die ritme van die alledaagse lewe verswelg en só vir alle praktiese doeleindes vergeet sal word. Dat hierdie verswelging as 'n onderdrukking van die ervaring van angstige disoriëntasie of as 'n verdediging teen die ervaring van gefrustreerde oriëntasiepogings gesien sou kon word, lyk vir my goed moontlik.

\section{Bibliografie}

Aerts, C. et al. 2003. "Asteroseismology of HD 129929: Core overshooting and nonrigid rotations", in Science, vol. 300, pp. 1926-1928.

Aerts, C. 2005. Kosmische Symfonieën, Intreerede as besondere hoogleraar in Astroseismologie aan die Radboud Universiteit Nijmegen.

Benveniste, E. 1966. "La notion de 'rythme' dans son expression linguistique”, in Problèmes de linguistique générale I, Paris: Gallimard, 1966, pp. 327-335.

Bourdieu, P. 1980. Le sens pratique, Paris: Editions de Minuit.

Geertz, C. [1973]2000. “Thick description. Toward an interpretive theory of culture”, in The interpretation of cultures: selected essays, New York: Basic Books, pp. 3-30.

Jonas, H. [1966]1982. The phenomenon of life. Toward a philosophical biology. Chicago \& London: University of Chicago Press.

Marquard, O. 1962. "Kant und die Wende zur Esthetik", in Zeitschrift für philosophische Forschung 16, pp. $231-243 \& 363-374$.

Meschonnic, H. 2002. "Rhytme [ling.]", in Les notions philosophiques II (Encyclopédie Philosophique Universelle), Sylvain Auroux (dir.), Paris: PUF, pp. 2288-2289.

Pascal, B. [1670]1961. Pensées, Ch.-M. des Granges (volgens die uitgawe van Brunschvicg), Paris: Garnier Frères.

Schibli, H. (sonder datum). "Pythagoreanism", in Routledge Encyclopedia of Philosophy, Edward Craig (ed.), CD-ROM Version 1.0, London: Routledge.

Sternenrest: http://www.sternenrest.nl (laaste keer geraadpleeg op 7 Augustus 2009). 
Thuan, T.X. 2008. "L'univers joue du jazz" (onderhoud), in La Vie 7-14 Augustus, pp. 18-24.

Wolff, E. 2007. "Mediologie en hermeneutiek", in Tydskrif vir Geesteswetenskappe 47/1, pp. 81-94.

Wolff, E. 2010. "Technicity of the body as part of the socio-technical system: the contributions of Mauss and Bourdieu" (sal in Theoria verskyn). 